\title{
Persuasive Communication of Parents to Establishment Social Intelligence for the Children
}

\author{
Zahratul Azizah ${ }^{1, *}$ \\ ${ }^{I}$ Department of Non Formal Education, Faculty of Education, Universitas Negeri Padang, Padang, Indonesia \\ "Email: zahratulazizah@fip.unp.ac.id
}

\begin{abstract}
Now entering the digital era, human life tinged with many facilities, something difficult or even impossible to be approached in the past, has become clear. All of this can be the positive or negative impact for generation, especially for children. Progress in technology never beneficial for people often abused, of course we do not want to technological advance in the digital era that affect social intelligence for child. Parents as the first and the foremost of educator in families have to give educate, teach, and infuse social values in communities with the approach of persuasive in the communication which are asking all without compulsion to children, so the children easily receive and sensitive with the social environment.
\end{abstract}

Keywords: social intelligence, persuasive communication, establishment, parenting

\section{INTRODUCTION}

The development of the field of technology and information that is increasingly rapid in the digital era now has a significant influence that has a variety of positive and negative impacts for all people especially the younger generation in this case children. When viewed from a positive impact technological progress makes it easy for us all to carry out all activities. Something that was once difficult to do even through a very long process but now with the sophistication of technology something that will be very easy to obtain. On the other hand, technological advances also have a negative impact. The presence of gadgets as a form of technological progress is often misused by the wearer. Features that are in the gadget provide a spectacle that is not all good even very much that damages the order of values and norms that apply in society such as watching acts of violence, fraud, and others are very easy to obtain. In addition, the presence of technology makes a person insensitive to the social environment and even technological advances have changed the existence of humans as social creatures. The phenomenon that appears now is a child engrossed in cyberspace where in his daily life many wrestle with android communication gadgets when guests come to the house indifferent children and can not show attitude in building social relationships with others, sometimes even showing a sense do not like because they feel disturbed by its activities. This means that children from childhood are used to activities that make them far from social values prevailing in the surrounding environment. In addition, the relationship between family members will also stay away, because parents are busy with their work routines without the opportunity to give attention and also education to their children. But if examined further, basically every child is born in a state of nature, both parents who make it Jewish, Christian, or majus. (Narrated by Bukhari). This means that the people who have the most role in the education of children from birth are parents. Parents as first and foremost educators in the family certainly have an important role here.

The family is a place of education that has a significant influence on the development and maturity of a child. A family is required to be able to make family members become families who are able to compete, be independent, have sensitivity to their social environment. Education carried out by parents in the family determines the success of their children's future.

Every child has the potentials that given God to him. One of them is the potential for social intelligence. Bustomi[1] said that to shape children's social development well, it must start early and start from the family environment. Of course here parents as educators in the family from the beginning have instilled social values to children set a good example and habituation to the social environment so that children can be imitated and emulated.

Several studies have shown that emotional intelligence, social intelligence, and spiritual intelligence are more influential for children's success in life in the future when compared to intellectual intelligence. This means that social intelligence must not be ignored. Someone who has good social intelligence will be good at communicating have lots of friends easy to adapt in a social environment and he is useful for many people.

Because of the importance of social intelligence for children of course parents in forming and developing children's social intelligence need to pay attention to various things in its delivery which of course is in communicating with children. Everything that is done by parents is communicated persuasively to the child, so that the child will indirectly accept it without compulsion. 


\section{DISCUSSION}

\subsection{Parents as Educators in the Family}

The family is one of the first and foremost educational institutions in the early process of children's education where the educators are parents. Parents in the family have function in forming individuals who have character and also as a place in preparing children to be able to live in the community. Parents consisting of fathers and mothers have a great responsibility in educating children in the family. They are not only play a role in meeting the physical needs of children such as eating, drinking, dressing, and living, more important than that they play a role in providing attention, guidance, education and instilling values for their future.

Ilham[2] said that the family has a major role in the formation of a network of social relationships needed by children in order to foster the ability to adapt, communicate, interact and interact with children. In its implementation, children's education in the family has a decisive role for the achievement of the quality of human resources. This is because through family education individuals first learn and recognize the cultural value system in the form of special rules, norms, habits, and examples from other communities. This means that in the family are taught various abilities and habits that will later be used by children in wading their lives in the community.

\subsection{Concept of Social Intelligence of Children}

Every child has various kinds of intelligence. Gardner[3] says that intelligence is the ability to solve problems, or create valuable products in one or several cultural and community environments. The intelligence that owned the child of course it needs to be shaped and developed so that later it will benefit their survival in the future.

Furthermore Gardner[3] argues that human intelligence is divided into eight types including (1) Intelligence Quotient (IQ), the potential ability of a person to learn something using thinking tools, this intelligence can be measured in terms of one's verbal strength and logic. This intelligence in general can be developed and encouraged by mothers, including formal education in schools. (2) Emotional Quotient (EQ) or emotional intelligence This intelligence has at least five main components namely self-awareness, emotional management, motivation, empathy and regulating a social relationship. This emotional intelligence was discovered by Daniel Goleman in his book Emotional Intelligence [4]. States that the contribution of IQ to one's success is only about $20 \%$ and the remaining $80 \%$ is determined by a series of factors which he calls emotional intelligence. (3) Spiritual Quotient (SQ) or spiritual intelligence that elevates the function of the soul as an internal device of the self that has the ability and sensitivity to see the meaning behind a certain reality or event. Spiritual intelligence is closely related to abilities that lead to enlighten the soul.

One intelligence possessed by children is social intelligence. Goleman[4] said that social intelligence is a measure of one's ability to interact in society and the ability to interact socially with people around or around him. In line with the opinions of the experts above. Prawira[5] said that social intelligence is the ability of individuals to deal with and react to social situations or live in society. Social intelligence is not a person's emotions towards others, but one's ability to understand others, can do something with the demands of society. Robbiyah, Ekasari, \& Witarsa[6] adds that social intelligence is enough to determine the ability of early childhood to foster self-concept and control emotions so that they can adjust to the social environment. These abilities must be possessed by a child in facing his life in the community.

Furthermore Agustian[7] said that social intelligence is the ability of a person to regulate his social life with intelligence, maintain emotional harmony, social, and disclosure through self-awareness skills, self-control, selfmotivation, empathy and social skills. It is clear that someone who has high social intelligence will be easily accepted in society because he has the ability to be able to understand others. Someone who has social intelligence is usually very well liked by his peers and good at getting along. He is also good at controlling his emotions able to face a problem and be able to solve the problem.

Goleman[8] argues that social intelligence is the ability to understand others and how to react to different social situations. There are two elements of social intelligence, namely social awareness and social facilities. Social awareness can be interpreted that a child must be sensitive to the environment in which he is. Children will feel what other people feel when experiencing an accident and he will empathize in this matter. Likewise with existing social facilities in the community of course children must be good at using existing facilities in the community good at maintaining it because the facility is shared with other community members.

\subsection{Persuasive Communication Approach}

The term of persuasion is taken from the English "persuation" which also comes from the Latin "persuasion" persuasion contains persuasion, seduction, convincing. Ritonga[9] says that persuasive communication is a conscious effort to change thoughts and actions by manipulating motives toward predetermined goals. This means that communication is done consciously without coercion in action.

Persuasive communication as any message that is intended to shape, reinforce, or change the responces of another, or others [10]. It mean is persuasive communication as one of the messages intended to form, strengthen, or change the response of others, how to communicate persuasively so that what we will convey to others can be understood and understood properly. 
Some definitions of persuasive communication above show that in communicating that is persuasive or inviting. The concept of inviting in this case must be based on the choice and use of words. The choice of words can be by using words that motivate not condescending others, using words and language that are similar and similar to the speaker as well as using appropriate expressions in responding to the other person.

\subsection{The Importance of Persuasive Communication from Parents in the Formation of Children's Social Intelligence}

Basically social intelligence in children can be formed. Armstrong[11] states that an important component of building social intelligence is communication and education. Education can not be obtained spontaneously, because indeed in education it takes the name of habituation and role models from within the family. Everything that parents do, will later be followed and imitated by children, of course, here needs good communication in delivering educational messages that parents do to children. Argiris[12] defines communication as a process in which a person, group, or organization (sender) sends information (massage) to another person, group, or organization (receiver).

Parents in delivering educational messages to their children sometimes experience interference. This disorder can be either not listened to messages or information given by parents by children. Perhaps the source of the cause came from the parents themselves. How to deliver educational messages by parents is sometimes not on time even not on target. Rebuke the child for example, when a child makes a mistake the child is immediately scolded without telling the child what his mistakes are, even worse is to scold the child while embarrassing the child in front of the crowd. This will psychologically lead to anger and hurt children to their parents so that all reprimands given by parents will not be heard and obeyed. This of course parents need to react to it so that such things do not happen. Not to mention the actions of parents who like to close the door when there are guests who ask for donations for a social activity, this indirectly parents teach children to be insensitive and sympathetic to their social environment.

Dowshen[13] states that the success of parents in educating children can not be separated from the communication patterns that exist between the two. There are so many parents whose intentions are to establish good communication with children but are actually received negatively by others. This can be illustrated how the intention of parents who want to motivate their children but is done by shouting, disparaging even worse is comparing children with others. The way of communication that parents do in this case will certainly have an psychological impact on children because the communication is very unpleasant for the child.
The key to success in establishing pleasant communication is how parents can have empathy for their children. Triwardhani[14] said that the keyword of how to understand and communicate well to children is empathy. Sometimes many parents have not been able to build sympathy for their children so that ultimately the communication that is built will fail. Parents who cannot build empathy children will feel a distance, in this case just the closeness and warmth of the parent's relationship with children is an absolute requirement that must exist if parents want to succeed in forming and developing social intelligence of their children.

Children's social intelligence can be formed and developed through a communication approach. The most important thing a parent and child can do when gathering and communicating is that no one party can force the will in truth both parties must listen to each other. Of course in this case parents must be more patient when they find their children conveying something that is not in accordance with the perspective of their parents because at this time the ability of parents is needed in terms of building a good dialogue with children and this is where capital is actually important in the development of children's intelligence.

The formation of children's social intelligence can be done including through persuasive communication by parents in the family. The development of a child's social intelligence starts from within the family because it is in the family the first and foremost education that forms the basis of the child's feet in his life as a social creature. Mother as one of the members in the family has an important role in developing children's social intelligence. For that reason, the family needs to be built conducive in the educational process and child care is good among others by providing a sense of security, giving love and acceptance, being a mainstay and direction, being a model of community life guidance, and being the main motivator in achieving success.

The development of social intelligence is very much influenced by the upbringing and encouragement of mothers. This is supported by the results of research conducted by Robbiyah, Ekasari \& Witarsa[6] which shows that the mother's parenting toward social intelligence of young children has a positive impact, which is very influential on children's social intelligence. The research explains that social intelligence determines the ability of early childhood to foster self-concept and control emotions so that they can adjust to the environment in order to be accepted and valued. The development of social intelligence is greatly influenced by mother's upbringing and encouragement, the extent to which the success of mother's upbringing is the extent of the involvement and role of mothers in the lives of their children. It is clear here that the contribution of a mother's role is decisive in the formation of a child's social intelligence. The mother has an extraordinary closeness with the child from the moment the child is in the womb where the child is physically and psychologically inseparable from the mother what the mother feels during pregnancy will also be felt by the child then when the child is born into the world the mother is breastfeeding the child, 
[5] P. A. Prawira, Psikologi Pendidikan: Dalam Perspektif Baru. Jogjakarta: Ar-Ruzz Media, 2012. into adulthood. Closeness and relationship with mother become the foundation of children's attitude in adjusting and learning to think about themselves in accordance with what their family members do. Everything a mother does spontaneously will be imitated and followed by her child. In the formation and development of children's social intelligence is strongly influenced by the example and personal touch that is full of love, attention and appreciation from parents especially mothers.

Alfiasari, Latifah, \& Wulandari[15] concluded in his research that parenting style has a close relationship with social intelligence. Parents who have an authoritarian parenting style usually have the habit of forcing the will on the child in every desire. Here the child is expected to obey all the commands given, of course this will cause the child will experience fear and even will reject all requests and teachings of his parents, which will automatically affect his social intelligence. It would be different if parents have a democratic parenting style, each discipline will always be communicated with their children.

Therefore it is important to provide good care by parents especially mothers who are due to their closeness to the child, which if done well, then this will be very memorable for children so that they can change children to continue to develop well into future generations of the family and the forerunner of society. Parents in the family become the main source of education for children, so parents, especially mothers, are the place for children to learn and take examples until finally the personality and character of the child will be formed.

\section{SUMMARY}

The formation of children's social intelligence needs to be done early on by parents in the family because this is very important in the survival of the child as a social creature who will always interact with others. The social intelligence of children formed by parents is carried out in a persuasive way, namely in the form of invitations, persuasions, seduction and not by coercion with good example examples so that what is taught and instilled by parents can be well received by children.

\section{REFERENCES}

[1] M. Y. Bustomi, Panduan Lengkap PAUD Melejitkan Potensi dan Kecerdasan Anak Usia Dini. Jakarta: Citra Publishing, 2012.

[2] W. Ilham, Menginstal Karakter Cerdas Anak. Bogor: Yayasan Lentera Istiqlal, 2011.

[3] H. Gardner, Multiple Intelligences. Batam Centre: Interaksara, 2003.

[4] D. Goleman, Emotional Intelligence. Jakarta: PT. Gramedia Pustaka Utama, 2006.
[6] Robbiyah, D. Ekasari, and R. Witarsa, "Pengaruh Pola Asuh Ibu terhadap Kecerdasan Sosial Anak Usia Dini di TK Kenanga Kabupaten Bandung Barat," J. Obs. J. Pendidik. Anak Usia Dini, vol. 2, no. 1, pp. 76-84, 2018.

[7] A. G. Agustian, ESQ: Emotional Spiritual Quotient. Jakarta: Arga Wijaya Persada, 2007.

[8] D. Goleman, Social Intelligence. Jakarta: PT. Gramedia Pustaka Utama, 2007.

[9] J. Ritonga, Tipologi Pesan Persuasif. Jakarta: Indeks, 2005.

[10] G. . Miller and Steinberg, Between People a New Analisys of Interpersonal Communication. Chicago: Science Research Associates, 1975.

[11] T. Armstrong, Multiple Intelligences in the Classroom. Alexandria, VA: Association for supervision and Curriculum Development, 1994.

[12] B. Ahsan, "Peranan Komunikasi Efektif di Dunia Bisnis," J. Ekon. STIE Haji Agus Salim Bukittinggi, vol. XV, no. 1, pp. 10-18, 2014.

[13] S. Dowshen, Cerdas Menjalin Komunikasi dengan Anak. Yogyakarta: Pionir Media, 2009.

[14] I. J. Triwardhani, "Komunikasi Persuasif pada Pendidikan Anak," J. Mediat., vol. 7, no. 1, pp. 77-84, 2005 .

[15] Alfiasari, M. Latifah, and A. Wulandari, "Pengasuhan Otoriter Berpotensi Menurunkan Kecerdasan Sosial, self-Esteem, dan Prestasi Akademik Remaja," J. ilmu, Kel. dan Konsum., vol. 4, no. 1, 2011. 